\title{
IMPLEMENTASI SISTEM INFORMASI WARGA BERBASIS WEB MENGGUNAKAN OPENSID DI DESA CIGOONG UTARA, KECAMATAN CIKULUR, KABUPATEN LEBAK
}

\author{
Ade Fauji ${ }^{*}$, Ahmad Ghifari², Rian Ristiawan ${ }^{3}$ \\ $1^{*}, 2,3$ Universitas Bina Bangsa \\ ahmadghifari484@gmail.com
}

\begin{abstract}
ABSTRAK
Seiring berkembangnya kemajuan teknologi mengakibatkan kebutuhan pengolahan data yang cepat, akurat, mudah dan peraktis menjadi sebuah tuntutan, sehingga saat ini mayoritas lembaga sudah memanfaatkan sistem pengelolaan data yang terkomputerisasi. Tidak terkecuali pengelolaan data dilembaga pemerintah desa, setiap desa diwajibkan memberikan pelayanan yang sebaik-baiknya kepada masyarakat dibidang pembuatan surat, pembayaran pajak, pendataan penduduk dan keperluan lain yang terkait dengan pelayanan dikantor desa. Tetapi sebagian besar proses pelayanan tersebut masih dilakukan secara konvensional. Oleh karna itu penulis merekomendasikan aplikasi pelayanan masyarakat berbasis web yang akan diterapkan di Desa Cigoong Utara. Aplikasi pelayanan desa ini dibuat berbasis web yang dapat digunakan secara online, jadi masyarakat Desa bisa menikmati layanan Desa dengan lebih cepat dan mudah. Diharapkan dengan adanya aplikasi layanan Desa ini, bisa meningkatkan kualitas proses pelayanan kepada masyarakat desa Cigoong Utara.
\end{abstract}

Kata kunci : Desa Cigoong Utara; Sistem Informasi Desa

\begin{abstract}
Along with the development of technological advances, the need for fast, accurate, easy and practical data processing has become a demand, so that currently the majority of institutions have utilized a computerized data management system. No exception for data management in village government institutions, each village is required to provide the best service to the community in the field of letter making, tax payments, population data collection and other needs related to village office services. But most of the service process is still done conventionally. Therefore, the author recommends a web-based public service application to be implemented in North Cigoong Village. This village service application is made web-based that can be used online, so village people can enjoy village services more quickly and easily. It is hoped that with the application of this village service, it can improve the quality of the service process to the people of North Cigoong village.
\end{abstract}

Keywords : North Cigoong Village; Village Information System 
Prosiding The 1st National Conference on Applied Business, Education, \& Technology (NCABET)"

Unversitas Bina Bangsa 2021

DOI Article : 10.46306/ncabet.v1i1.19

\section{PENDAHULUAN}

Sistem informasi adalah seperangkat komponen yang menghubungkan, mengumpulkan, memproses, menyimpan, dan mendistribusikan informasi untuk mendukung pembuatan keputusan dan pengawasan dalam suatu organisasi (Subari, 2017). Ketersedian informasi yang akurat dan selalu diperbarui sudah menjadi kebutuhan pokok saat ini. Ketersediaan informasi ini dibutuhkan tidak hanya oleh seseorang tetapi juga oleh organisasi dan institusi serta birokrasi (Subari, 2018). Dalam bidang birokrasi, salah satu informasi yang dibutuhkan adalah informasi kependudukan. Infromasi yang akurat dan selalu diperbarui dalam bidang kependudukan akan memudahkan pengelola birokrasi untuk menjalankan tugas utamanya yaitu memberikan pelayanan yang optimal kepada masyarakat (penduduk/warga).

Pada saat ini sedang dikembangkan sebuah sistem kependudukan secara terpadu pada tingkat nasional. Namun demikian, implementasi dari sistem ini belum sepenuhnya optimal. Selain pemuatan data yang belum seratus persen, akses sistem juga belum dapat dilakukan diseluruh sistem birokrasi yang ada. Oleh karena itu keberadaan sistem-sistem pendukung tetap dibutuhkan untuh melayani kebutuhan data kependudukan yang akurat dan selalu diperbarui ditingkat birokrasi terendah, dalam hal ini adalah tingkat desa.

Hal ini juga terjadi di Desa Cigoong Utara, Kecamatan Cikulur, Kabupaten Lebak yang berlokasi di perbatasan antara Desa Curug Panjang dan Desa Cigoong Selatan. Gambar 1 menunjukkan lokasi dari Desa Cigoong Utara, Kecamatan Cikulur, Kabupaten Lebak. Walaupun termasuk daerah yang relatif cukup maju namun layanan informasi dan berkas administrasi kependudukan belum diberikan sepenuhnya secara efektif, oleh karenanya memerlukan sistem informasi data kependudukan yang cukup mudah di akses, cepat, akurat dan up to date. Sehubungan dengan hal tersebut, pengabdian ini bertujuan untuk merekomendasikan sebuah aplikasi kependudukan yang dapat dimanfaatkan pada tingkat desa di Desa Cigoong Utara, Kecamatan Cikulur, Kabupaten Lebak.

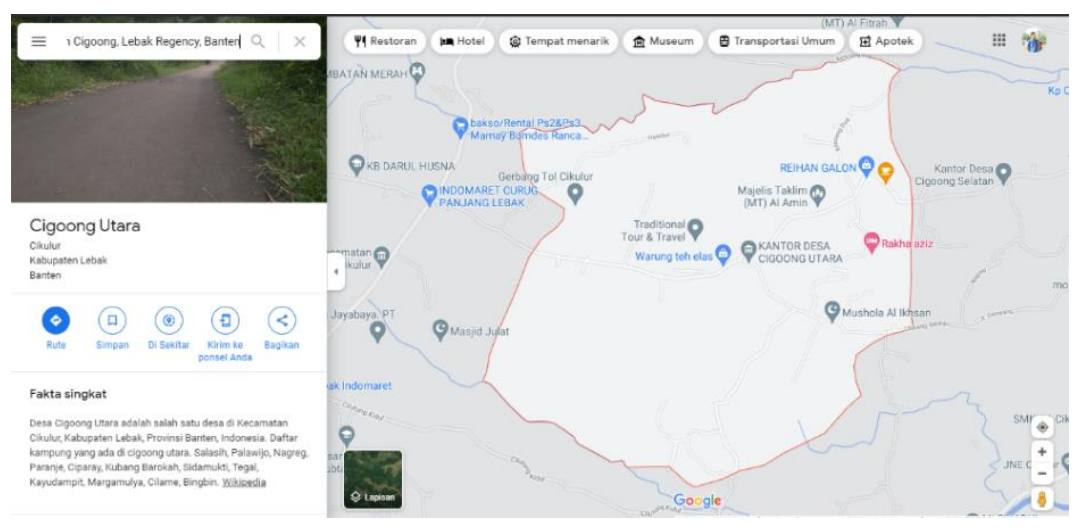

Gambar 1 Lokasi Desa Cigoong Utara, Kecamatan Cikulur, Kabupaten Lebak 
Prosiding The 1st National Conference on Applied Business, Education, \& Technology (NCABET)”

Unversitas Bina Bangsa 2021

DOI Article : 10.46306/ncabet.v1i1.19

\section{METODE PELAKSANAAN}

Pengabdian di Desa Cigoong Utara, Kecamatan Cikulur, Kabupaten Lebak dilaksanakan melalui beberapa tahapan berikut : melakukan perijinan pelaksanaan kegiatan kepada pihak terkait, melakukan pengumpulan data-data terkait, melakukan pengumpulan data-data terkait, merancang dan membuat aplikasi sistem informasi warga Desa Cigoong Utara, Kecamatan Cikulur Kecamatan Lebak berdasarkan data-data yang diperoleh, melakukan pengujian aplikasi tersebut untuk mengetahui apakah aplikasi tersebut sesuai dengan kebutuhan (Subari, 2019).

Tahap pertama kegiatan adalah proses perijinan kegiatan pengabdian masyarakat yang dilakukan kepada pemerintah daerah setempat. Proses perijinan dilakukan dengan melaksanakan komunikasi informal dengan perangkat Desa Cigoong Utara. Langkah berikutnya adalah melakukan komunikasi formal dengan mengirimkan surat permohonan kegiatan pengabdian ke Kepala Desa Cigoong Utara yang ditembuskan ke Kecamatan Cikulur sebagai laporan.

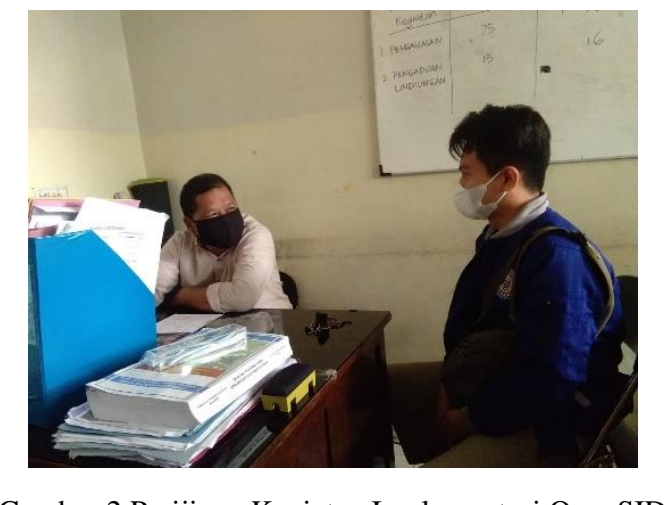

Gambar 2 Perijinan Kegiatan Implementasi OpenSID

Kegiatan survey dan pengumpulan data merupakan tahapan kedua dalam kegiatan pengabdian ini. Pengumpulan data difokuskan pada informasi-informasi terkait yang dibutuhkan dalam perancangan sistem informasi kependudukan yang berada di desa.

Langkah berikutnya adalah melakukan perancangan sistem informasi berdasarkan data yang sudah disiapkan. Perancangan dan pembuatan sistem informasi dilakukan dengan memanfaatkan CMS (Custom Manajemen System) yang dikembangkan oleh Komunitas OpenSID dengan aplikasi yang dapat di akses di https://opendesa.id/. Perancangan aplikasi dilakukan dengan melaksanakan penyesuaian data dan tampilan pada CMS sesuai dengan data dan kebutuhan di Desa Cigoong Utara. Langkah pertama adalah melakukan penyesuaian tampilan sesuai dengan kebutuhan atau disebut dengan perancangan interface. Perancangan interface dilakukan untuk membangun tampilan yang user friendly bagi pengguna, namun tetap memberikan fungsi yang diinginkan (Mauladi, 2016). Ini merupakan salah satu langkah penting dalam pengembangan sistem informasi (Subari, 2020). Penyesuaian tampilan dilakukan dengan mengisikan data-data nama dan informasi desa, lokasi pada maps, setting tampilan pada halaman utama serta penambahan fitur untuk dashboard pada tampilan 
untuk umum. Database berguna untuk mengelola keberadaan data-data yang dibutuhkan oleh aplikasi seperti create, edit dan update (Subari, 2020; Sucipto, 2017). Tahap ini dimulai dengan menyusun struktur database berdasarkan tabel yang digunakan dan hubungannya dengan tabel lainnya. Dalam hal ini dilakukan dengan cara memanfaatkan fitur import yang telah disiapkan oleh sistem opendesa. Berikutnya melakukan proses import data dalam bentuk formal excel tersebut ke dalam sistem informasi dengan memanfaatkan fitur import di sistem (Open SID, 2019).

Tahapan berikutnya adalah melakukan pengujian terhadap sistem informasi yang telah disiapkan sesuai dengan tampilan dan data yang telah disesuaikan. Tujuan pengujian ini adalah untuk memastikan bahwa tampilan aplikasi sudah sesuai dengan informasi yang dibutuhkan serta data yang ditampilkan adalah data yang tepat, dalam hal ini adalah data kependudukan dari Desa Cigoong Utara.

Setelah dilakukan pengujian, langkah berikutnya adalah melakukan implementasi program dan pemasangan perangkat di tempat yang ditetapkan. Pelaksanaan implementasi program dilaksanakan di Balai Desa Cigoong Utara dengan melibatkan beberapa pihak yaitu dosen, mahasiswa serta perangkat dari Desa Cigoong Utara, Kecamatan Cikulur, Kabupaten Lebak.

\section{HASIL DAN PEMBAHASAN}

Pelaksanaan pengabdian dilakukan berdasarkan rancangan yang sudah dibuat sebelumnya. Pada tahap implementasi, langkah pertama adalah dengan melakukan koordinasi dengan pihak terkait. Dalam tahapan ini disampaikan informasi teknis serta rencana lokasi implementasi sistem informasi dengan lebih detail dan pasti.

Partisipasi, bantuan dan koordinasi yang baik dengan perangkat Desa Cigoong Utara, Kecamatan Cikulur, Kabupaten Lebak sangat berguna dalam kelancaran kegiatan pengabdian ini. Peserta cukup antusias dalam mengikuti kegiatan pengabdian ini dengan penuh kerelaan dan terbuka mamberikan informasi dan bantuan sehingga proses implementasi, dalam bentuk instalasi perangkat dan uji cobanya berjalan dengan baik dan lancar. Peserta juga cukup aktif dalam berdiskusi dalam hal pemanfaatan dan operasional sistem informasi dengan harapan bahwa tidak terkendala di kemudian hari.

Hasil dari kegiatan ini adalah terdapat sistem informasi warga berbasis web yang dapat menyajikan data-data kependudukan yang sering dibutuhkan dengan cepat, akurat dan up to date. Dengan sistem informasi ini data-data kependudukan dapat disajikan lebih cepat daripada cara manual. Screenshot aplikasi ini ditunjukkan pada Gambar 2. 


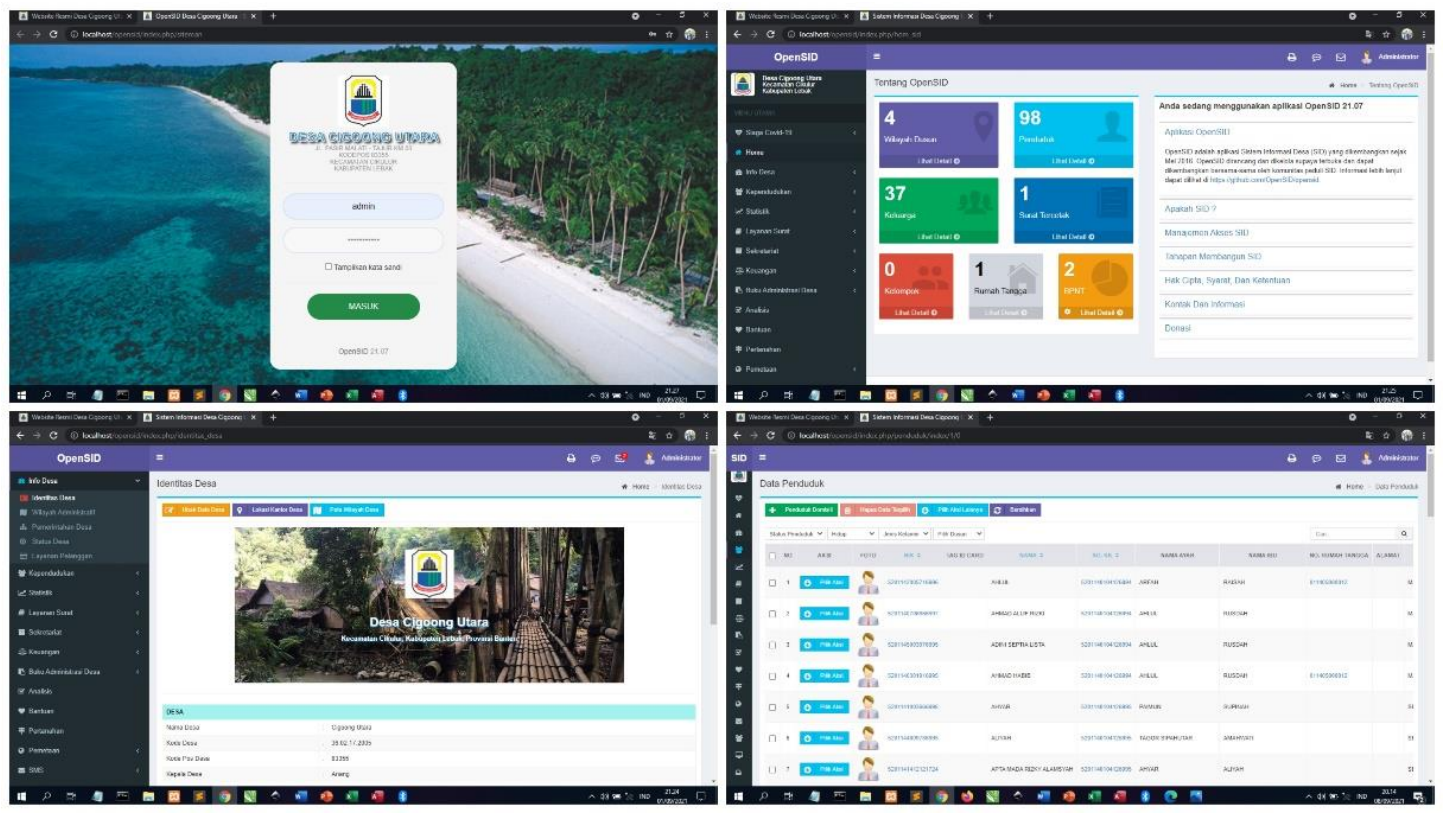

Gambar 3 Screenshot Aplikasi OpenSID Desa Cigoong Utara

\section{KESIMPULAN}

Kegiatan pengabdian ini telah menghadirkan sistem informasi kependudukan yang lebih baik di Desa Cigoong Utara, Kecamatan Cikulur, Kabupaten Lebak. Pelaksanaan kegiatan pengabdian telah dilakukan sesuai dengan tahapan-tahapan yang dibuat pada proses perancangan dan perencanaan. Dengan adanya sistem informasi kependudukan ini diharapkan data-data kependudukan dan berkas administrasi desa di Desa Cigoong Utara, Kecamatan Cikulur, Kabupaten Lebak dapat disajikan dengan lebih cepat, akurat dan up to date.

\section{UCAPAN TERIMA KASIH}

Ucapan terima kasih kami sampaikan kepada Kepala Desa Cigoong Utara serta perangkat desa nya yang sangat antusias dalam kegiatan ini. Selain itu juga kepada teman-teman mahasiswa kelompok 66 KKM-TEMATIK UNIBA 2021 yang banyak mendukung terselengaranya kegiatan pengabdian ini. 


\section{DAFTAR PUSTAKA}

A. Subari, S. Manan, E. Ariyanto, Implementation of Password Guessing Resistant Protocol (PGRP) in improving user login security on Academic Information System, International Conference on Vocational Studies and Applied Research, 2017.

A. Subari, Development of Information System Based on Web Application for Measuring Educational Performance Indicator Using Codeigniter Framework, Advanced Science Letters, 24(12) pp 9520-9522(3), 2018.

Fahrur, R. (2017). Pengembangan website dan sistem informasi desa di kabupaten tulungagung. 02, 107-112.

Github.com. (2018). Peran dan Manfaat Sistem Informasi Desa. Retrieved from https://github.com/OpenSID/OpenSID/wiki/Perandan Manfaat Sistem-Informasi-Desa

H. Jalma, R. E. Putera, and K. Kusdarini,2019. "E-Government dengan Pemanfaatan Web OpenSID dalam Pelayanan Publik di Nagari TanjungHaro Sikabu-kabu Padang Panjang," Publik (Jurnal Ilmu Adm., 2019.

Ibad., M. I. (2016). Memahami Sistem Informasi dalam Konteks UU Desa. Retrieved May 20, 2018, from https://sekolahdesa.or.id/tag/sisteminformasi-desa/

Kartika, Yuli. 2013. Dalam Jurnal Aplikasi e-government pada Desa Sinar Harapan Kabupaten Tanggamus.Komunitas Open SID, Panduan Penggunaan Aplikasi Open SID, 2019

Sucipto, Design of Active Database System in Market Price Service Information Systems, Intensif Journal, 1(1) pp 35-43, 2017.

Ridwan, E. (2017). Peran dan Manfaat Sistem Informasi Desa. Retrieved April 6, 2018, from https://github.com/OpenSID/OpenSID/wiki/Peran-dan-Manfaat-Sistem-Informasi-Desa

Riyanto, I. Santiko, and A. M. Wahid, 2018. "Sistem Informasi Kependudukan dan Pelayanan Administrasi Desa," in CITISEE 2018,.

Wibawa, K. C. S. 2019. "Urgensi Keterbukaan Informasi dalam Pelayanan Publik sebagai Upaya Mewujudkan Tata Kelola Pemerintahan yang Baik,” Adm. Law Gov. J.,. 